\title{
Karakteristik Gelombang Laut di Perairan Laut Natuna Menggunakan Data Satelit Altimetri
}

\author{
Obbi Sanjaya $^{a *}$, Muliadia $^{\mathrm{a}}$, Apriansyah ${ }^{\mathrm{b}}$
}

\author{
aProdi Geofisika, FMIPA Universitas Tanjungpura, bProdi Kelautan, FMIPA Universitas Tanjungpura \\ *Email : obbi.sanjaya@gmail.com
}

\begin{abstract}
Abstrak
Perairan Laut Natuna merupakan salah satu wilayah laut Indonesia yang sebagian besar wilayahnya digunakan sebagai kawasan aktifitas pelayaran. Tinggi gelombang sebagai salah satu faktor keselamatan aktifitas pelayaran perlu diketahui guna menciptakan kelancaran dalam beraktifitas. Oleh karena itu informasi mengenai karakteristik tinggi gelombang laut di Perairan Laut Natuna dibutuhkan masyarakat dalam aktifitas pelayaran. Penelitian ini telah dilakukan bertujuan untuk menggambarkan karakteristik gelombang menggunakan parameter gelombang signifikan sebagai acuan pelayaran yang terbentuk di permukaan laut dari hasil pengamatan teknologi penginderaan jauh yaitu produk satelit altimetri Jason dalam memberikan kontribusi informasi pelayaran. Data yang digunakan pada penelitian ini yaitu data satelit altimetri RADS (Radar Altimeter Database System) Jason dari tahun 2007 s.d 2016 diproses menggunakan software BRAT 4.1 dengan metode "BratAlgoFilterLoessGrid". Hasil penelitian kemudian diklasifikasikan menggunakan skala laut douglas untuk mengetahui klasifikasi karakteristik tinggi gelombang laut yang terbentuk. Berdasarkan hasil analisis komparasi data penelitian dengan data milik BMKG diketahui bahwa terdapat perbedaan hasil pengamatan tinggi gelombang laut signifikan. Terakhir hasil analisis tinggi gelombang laut didapatkan rata-rata di Perairan Laut Natuna sebesar 1,42 $\mathrm{m}$ dan karakteristik gelombang laut menurut skala laut douglas berada di skala 4 yaitu tinggi gelombang sedang.
\end{abstract}

Kata Kunci : Gelombang Laut, RADS, BratAlgoFilterLoessGrid, Skala Laut Douglas

\section{Pendahuluan}

Perairan Laut Natuna merupakan satu diantaranya perairan laut di Indonesia bagian Barat yang mempunyai posisi strategis untuk kepentingan perekonomian dunia dengan perannya sebagai bagian dalam rute pelayaran Internasional [1]. Namun demikian, aktifitas pelayaran yang terjadi di perairan Laut Natuna bisa mengalami kendala akibat kurangnya informasi tentang parameter fisik di bidang kelautan. Salah satunya gelombang laut penting dalam pelayanan informasi meteorologi kelautan (marine meteorological services) [2].

Penelitian yang mengkaji tinggi gelombang laut telah dilakukan Mulyadi et.al (2015) pada kawasan perairan Selat Karimata menggunakan metode Sverdrup Munck Bretschneider (SMB) tahun 2005 s.d 2013. Dalam penelitian ini tinggi gelombang laut dibagi menjadi 4 musim yaitu pada musim barat tingginya berkisar antara 0,79 s.d 1,49 m. Musim peralihan I, tingginya berkisar antara 0,34 s.d 0,73 m. Musim timur, tingginya berkisar antara 0,50 s.d 1,42 m. Musim peralihan II, tingginya berkisar antara 0,51 s.d $1,05 \mathrm{~m}$ [3].

Penelitian tersebut memiliki kelemahan yaitu penentuan tinggi gelombang laut didapatkan dari hasil peramalan gelombang (hindcasting) menggunakan data sekunder kecepatan angin yang dianalisi ulang dengan model lain. Berdasarkan hal tersebut, selanjutnya kajian dilakukan pada Perairan Laut Natuna menggunakan proses retracking data Radar Altimeter Database System (RADS) dengan metode "BratAlgoFilterLoessGrid" untuk mendapatkan hasil data significant wave height (swh) yaitu data tinggi gelombang laut signifikan. Hasil dari penelitian ini diharapkan masyarakat bisa lebih mengetahui dan memahami keadaan tinggi gelombang laut yang terbentuk di Perairan Laut Natuna dan informasinya bisa digunakan sebagai navigasi pelayaran dalam beberapa tahun kedepan.

\section{Metodologi \\ 2.1 Wilayah Penelitian}

Penelitian dilakukan pada wilayah perairan Laut Kalimantan Barat terletak di koordinat $2^{\circ} 50^{\prime}$ LU serta $2^{\circ} 30^{\prime}$ LS serta diantara $105^{\circ} 00^{\prime}$ BT dan $110^{\circ} 30^{\prime}$ BT. Lokasi penelitian dibagi menjadi 3 segmen $\mathrm{A}, \mathrm{B}$, dan $\mathrm{C}$ dengan luas domain dapat dilihat pada Tabel 1 dan Peta wilayah penelitian dapat dilihat pada Gambar 1.

Tabel 1. Luas Domain Segmen Penelitian

\begin{tabular}{cc}
\hline Segmen & Luas Domain \\
\hline A & $2^{\circ} 50^{\prime}$ LU s.d $1^{\circ} 00^{\prime}$ LU serta $105^{\circ} 00^{\prime}$ BT s.d $110^{\circ} 00^{\prime}$ BT \\
B & $1^{\circ} 00^{\prime}$ LU s.d $1^{\circ} 00^{\prime}$ LS serta $105^{\circ} 00^{\prime}$ BT s.d $109^{\circ} 00^{\prime}$ BT \\
C & $1^{\circ} 00^{\prime}$ LS s.d $2^{\circ} 30^{\prime}$ LS serta $105^{\circ} 00^{\prime}$ BT s.d $110^{\circ} 00^{\prime}$ BT \\
\hline
\end{tabular}

\subsection{Data Penelitian}

Data yang digunakan adalah data $R A D S$ satelit altimetri Jason-1, Jason-2 dan Jason-3 pengamatan dari tahun 2007 s.d 2016. Data diunduh dari penyimpanan server utama satelit 
altimetri multi-misi (http://rads.tudelft.nl/rads /rads.shtml)[4].

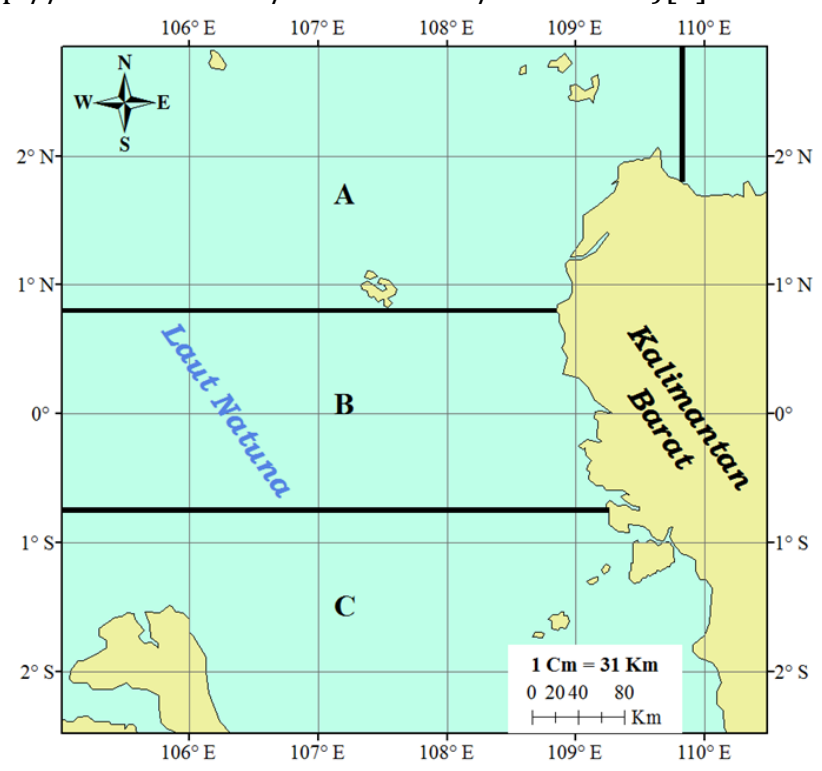

Gambar 1. Peta Wilayah Penelitian (Segmen A : Perairan Kep. Anambas, Laut Natuna, Perairan Singkawang. Segmen B : Laut Natuna, Perairan Pontianak. Segmen C : Laut Natuna, Selat Karimata bagian Utara)

\subsection{Pengolahan Data}

\subsubsection{Pengambilan Data}

Pengambilan data RADS yang digunakan adalah satelit altimetri Jason-1, Jason-2 dan Jason-3. Kemudian setting fase misinya dilakukan secara manual. Data swh yang diolah sendiri dapat ditulis dengan persamaannya sebagai berikut [5] :

$$
\begin{aligned}
S W H^{2}= & a^{2}\left(\sigma_{c}^{2}-\sigma_{p}^{2}\right) \\
\text { Dengan : } & \\
S W H^{2}= & \text { Tinggi Gelombang laut } \\
& \text { signifikan } \\
a^{2} \quad= & \text { Sebuah konstanta } \\
\sigma_{c}^{2} \quad= & \text { Kemiringan bentuk waveform } \\
\sigma_{p}^{2} \quad= & \text { Parameter instrumen } \\
& \text { waveform }
\end{aligned}
$$

\subsubsection{Kontrol Kualitas Data}

Kontrol kualitas yang digunakan adalah significant wave height. Kriteria data yang digunakan yaitu $0 \mathrm{~mm} \leq \mathrm{swh} \_\mathrm{ku} \leq 11.000 \mathrm{~mm}$ berdasarkan acuan yang dikeluarkan oleh PODAAC dan AVISO terlihat pada Tabel 1.

\subsubsection{Perhitungan Tinggi Gelombang}

Perhitungan tinggi gelombang laut menggunakan software BRAT 4.1 dengan setting sebagai berikut :

\begin{tabular}{|c|c|c|}
\hline No & Macam Data & Kriteria Data \\
\hline 1 & $\begin{array}{l}\text { Jumlah pengamatan } \\
\text { valid }\end{array}$ & range_numval_ku $\geq 10$ \\
\hline 2 & $\begin{array}{l}\text { RMS jarak altimeter } \\
\text { dalam }\end{array}$ & $0 \mathrm{~mm} \leq$ range_rms_ku $\leq 200$ \\
\hline 3 & Altitude - Range_ku & $\begin{array}{l}-130.000 \mathrm{~mm} \leq \text { altitude }- \\
\text { range_ku } \leq 100.000 \mathrm{~mm}\end{array}$ \\
\hline 4 & $\begin{array}{l}\text { Koreksi troposfer } \\
\text { kering }\end{array}$ & $\begin{array}{l}-2.500 \mathrm{~mm} \leq \text { model_dry } \\
\text { tropo_corr } \leq-1.900 \mathrm{~mm}\end{array}$ \\
\hline 5 & $\begin{array}{l}\text { Koreksi troposfer } \\
\text { basah }\end{array}$ & $\begin{array}{c}-500 \mathrm{~mm} \leq \text { rad_wet_tropo } \\
\text { _corr } \leq-1 \mathrm{~mm}\end{array}$ \\
\hline 6 & Koreksi ionosfer & $\begin{array}{c}-400 \mathrm{~mm} \leq \text { iono_corr_alt_ku } \leq \\
40 \mathrm{~mm}\end{array}$ \\
\hline 7 & $\begin{array}{l}\text { Bias Elektromagnetik } \\
\text { (EMB) }\end{array}$ & $\begin{aligned}-500 \mathrm{~mm} & \leq \text { sea_state_bias_ku } \\
& \leq 0 \mathrm{~mm}\end{aligned}$ \\
\hline 8 & $\begin{array}{c}\text { Koreksi pasang surut } \\
\text { laut }\end{array}$ & $\begin{array}{c}-5.000 \mathrm{~mm} \leq \text { ocean_tide_sol1 } \\
\leq 5.000 \mathrm{~mm}\end{array}$ \\
\hline 9 & $\begin{array}{l}\text { Koreksi pasang surut } \\
\text { pembebanan }\end{array}$ & $\begin{array}{c}-1.000 \mathrm{~mm} \leq \text { solid_earth_tide } \\
\leq 1.000 \mathrm{~mm}\end{array}$ \\
\hline 10 & $\begin{array}{l}\text { Koreksi pasang surut } \\
\text { kutub }\end{array}$ & $\begin{array}{c}-150 \mathrm{~mm} \leq \text { pole_tide } \leq \\
150 \mathrm{~mm}\end{array}$ \\
\hline 11 & $\begin{array}{c}\text { Significant Wave } \\
\text { Height }\end{array}$ & $0 \mathrm{~mm} \leq \mathrm{swh} \_\mathrm{ku} \leq 11.000 \mathrm{~mm}$ \\
\hline 12 & Sigma Naught & 10 \\
\hline 13 & Kecepatan angin & $\begin{array}{c}0 \mathrm{~m} / \mathrm{s} \leq \text { wind_speed_alt } \leq 30 \\
\mathrm{~m} / \mathrm{s}\end{array}$ \\
\hline 14 & $\begin{array}{l}\text { Square of off nadir } \\
\text { angle }\end{array}$ & $\begin{array}{c}0.2 \text { deg2 } \leq \text { off_nadir_angle } \\
\text { ku_wvf } \leq 0.16 \text { deg2 }\end{array}$ \\
\hline
\end{tabular}

Periode Tahun : 1 Januari 2007 - 1 Januari 2017 Domain $\quad: 2^{\circ} 50^{\prime} \mathrm{LU}$ s.d $2^{\circ} 30^{\prime} \mathrm{LS}, 105^{\circ} 00^{\prime}$

$$
\text { BT s.d } 110^{\circ} 30^{\prime} \mathrm{BT}
$$

Res Spasial $\quad: 0,33^{\circ} \times 0,33^{\circ}( \pm 37,1 \times 37,1 \mathrm{Km})$

Res Temporal : Tiap 10 hari/ 1cycle

Metode input : "BratAlgoFilterLoessGrid"
Tabel 2. Kontrol Kualitas Data Satelit Altimetri Sumber: OSTM/Jason-2 Products Handbook [6]

Metode BratAlgoFilterLoessGrid merupakan filter loess ataupun filter low-pass yang algoritmanya didasarkan pada regresi lokal menggunakan Weighted Least Square dan model polinomial tingkat 2 [7].

Kriteria Weighted Least Square dapat ditulis sebagai berikut :

$$
(y-X \beta)^{T} K_{h}(y-X \beta)
$$


Dengan :

$$
\begin{aligned}
& \mathrm{y}=\text { Data swh } \\
& X=\left[\begin{array}{ccccc}
1 & \left(x_{1}-x_{0}\right) & \left(x_{1}-x_{0}\right)^{2} & \ldots & \left(x_{1}-x_{0}\right)^{2} \\
1 & \left(x_{2}-x_{0}\right) & \left(x_{2}-x_{0}\right)^{2} & \cdots & \left(x_{2}-x_{0}\right)^{2} \\
\vdots & \vdots & \vdots & \ddots & \vdots \\
1 & \left(x_{n}-x_{0}\right) & \left(x_{n}-x_{0}\right)^{2} & \cdots & \left(x_{n}-x_{0}\right)^{2}
\end{array}\right] \\
& \beta=\left[\begin{array}{lll}
\beta_{0}\left(x_{0}\right) \beta_{1}\left(x_{0}\right) & \cdots & \beta_{p}\left(x_{0}\right)
\end{array}\right]^{T} \\
& K=\text { fungsi kernel } \\
& h=\text { bandwidth }
\end{aligned}
$$

Model polinomial tingkat 2 dapat ditulis sebagai berikut :

$$
\hat{y}=\beta_{0}+\beta_{1}+\beta_{2} x^{2}
$$

\subsubsection{Pembuatan Peta Gelombang laut}

Hasil perhitungan tinggi gelombang laut kemudian dibuat dalam bentuk peta yang terdiri dari pengamatan 10 tahun terakhir dan tiap tahunnya dimulai dari tahun 2007 s.d 2016. Klasifikasi karakteristik tinggi gelombang laut dibuat dalam bentuk peta skala laut douglas [8].

\subsection{Analisis Hasil Penelitian}

Sebelum hasil penelitian dianalisis, terlebih dahulu dikomparasikan dengan hasil model lain untuk memastikan apakah ada kesamaan atau tidak dengan data hasil penelitian. Proses komparasi data hasil penelitian dilakukan dengan data hasil running model Windwave-05 oleh BMKG yang menggunakan data arah dan kecepatan angin untuk mendapatkan variabilitas tinggi gelombang laut.

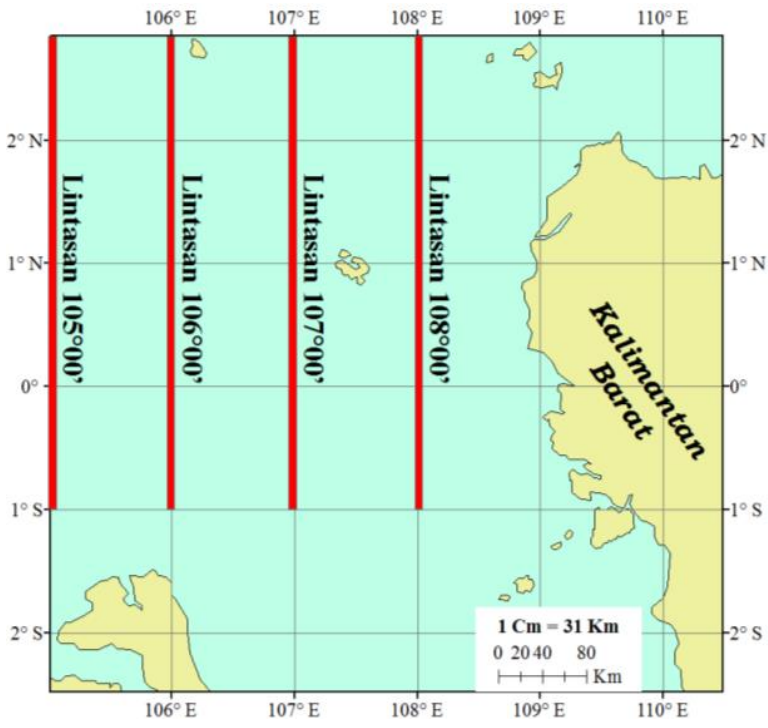

Gambar 2. Skema Penentuan dan Pengambilan Sampel Data Komparasi
Sampel proses komparasi yang digunakan yaitu sebanyak 48 titik pengamatan pada hasil penelitian dan sebanyak 36 titik pengamatan pada data $\mathrm{BMKG}$ yang tersebar disemua lintasan $105^{\circ} 00^{\prime}, 106^{\circ} 00^{\prime}, 107^{\circ} 00^{\prime}$ dan $108^{\circ} 00^{\prime}$. Skema lintasannya dapat dilihat pada Gambar 2.

Metode yang digunakan pada analisis komparasi merupakan Uji-T dua variabel dengan menggunakan persamaan sebagai berikut :

$$
t_{\text {hitung }}=\frac{\bar{x}_{1}-\bar{x}_{2}}{\sqrt{\left(\frac{\left(n_{1}-1\right) \sigma_{1}+\left(n_{2}-1\right) \sigma_{2}}{n_{1}+n_{2}-2}\right)\left(\frac{1}{n_{1}}+\frac{1}{n_{2}}\right)}}
$$

$\mathrm{dk}=n_{1}+n_{2}-2$

dengan $\bar{x}_{1}$ rata-rata sampel ke- $1, \bar{x}_{2}$ rata-rata sampel ke-2, $\sigma_{1}$ varians sampel ke- $1, \sigma_{2}$ varians sampel ke-2, $n$ jumlah sampel dan $\mathrm{dk}$ adalah derajat kebebasan.

Setelah proses komparasi selesai, kemudian dilakukan analisis tinggi gelombang laut untuk mencari nilai tinggi rata-rata, minimum dan maksimum pada persebaran data tinggi gelombang laut di Laut Natuna. Jumlah titik pengamatan dari hasil mengolah data satelit altimetri Jason di Perairan Laut Natuna yaitu sebanyak 120 dan untuk skema titik pengamatannya dapat dilihat pada Gambar 3.

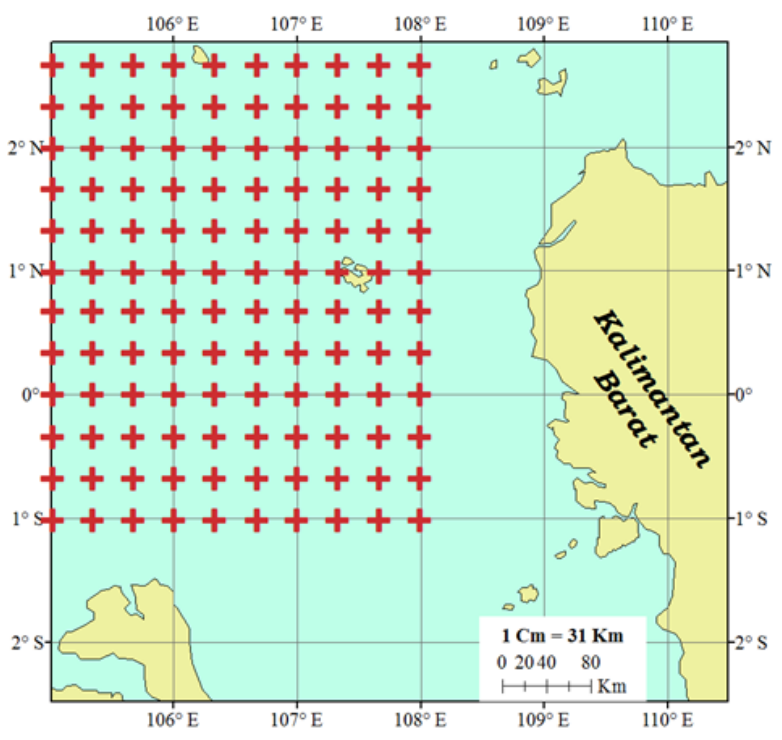

Gambar 3. Skema Titik Pengamatan di Perairan Laut Natuna 


\subsection{Bagan Alir}

Penjelasan kegiatan dari awal sampai akhir suatu penelitian dapat dilihat pada Gambar 4 dan proses menjelaskan pengolahan data sampai pada tahap menganalisis data hasil penelitian dapat dilihat pada Gambar 5.

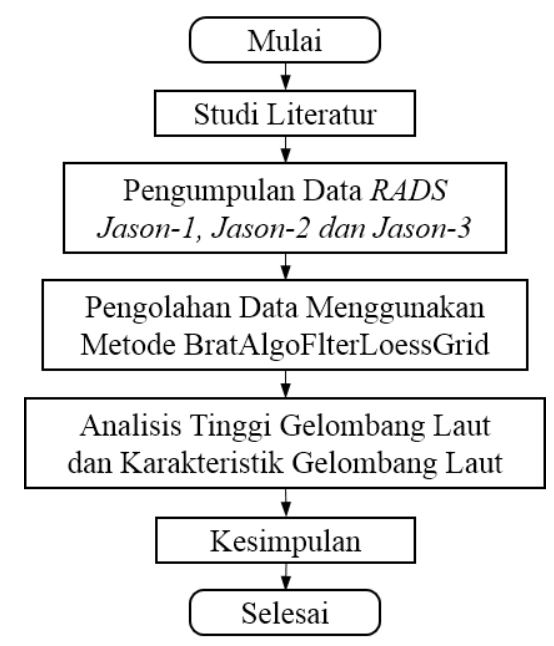

Gambar 4. Bagan Alir Penelitian

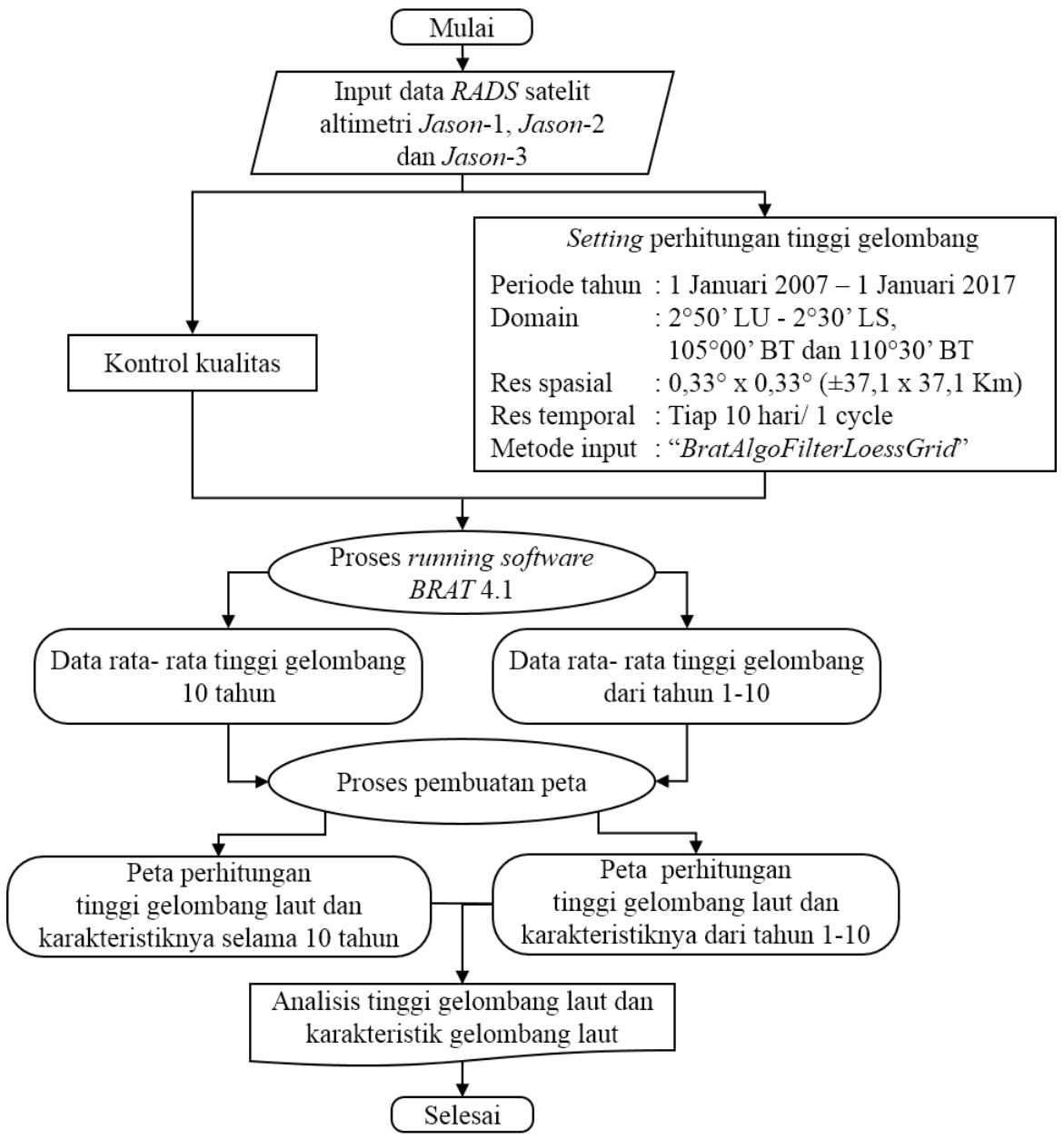

Gambar 5. Bagan Alir Pengolahan Data dan Kajian 


\section{Hasil dan Pembahasan}

3.1 Perbandingan Tinggi Gelombang Antara Data Hasil Penelitian Dengan Data BMKG

Data tinggi gelombang laut hasil penelitian dibandingkan terhadap data tinggi gelombang laut hasil running model Windwave-05 oleh BMKG dengan menggunakan data arah dan kecepatan angin untuk mendapatkan variabilitas tinggi gelombang laut. Kemudian setelah dilakukan Uji-T dengan menentukan hipotesis penelitian sebagai berikut:

Ho = Tidak terdapat perbedaan hasil pengamatan rata-rata tinggi gelombang laut menggunakan metode BratAlgoFilter LoessGrid dengan metode Windwaves-05, dan

$\mathrm{Ha}=$ Terdapat perbedaan hasil pengamatan rata-rata tinggi gelombang laut menggunakan metode BratAlgoFilter LoessGrid dengan metode Windwaves-05 hipotesis statistiknya $=$ Ho $: \mu_{1} \leq \mu_{2}$ dan Ha: $\mu_{1}>\mu_{2}$

kriteria pengujian yaitu satu arah penerimaan jika $t_{\text {hitung }} \leq t_{\text {tabel }}$ maka Ho diterima, dan $t_{\text {hitung }}>t_{\text {tabel }}$ maka Ha diterima. Hasil komparasi data dapat dilihat pada Tabel 3.

Tabel 3. Hasil Uji-T

\begin{tabular}{ccccc}
\hline Lintasan & $t_{\text {hitung }}$ & $t_{\text {tabel }}$ & $\begin{array}{l}\text { Hipotesis } \\
\text { Statistik }\end{array}$ & Keterangan \\
\hline $105^{\circ} 00^{\prime}$ & 7,55 & 1,73 & $\begin{array}{l}t_{\text {hitung }} \\
>t_{\text {tabel }}\end{array}$ & Ha diterima \\
$106^{\circ} 00^{\prime}$ & 7,63 & 1,73 & $\begin{array}{l}t_{\text {hitung }} \\
>t_{\text {tabel }}\end{array}$ & Ha diterima \\
& & & $\begin{array}{l}t_{\text {hitung }} \\
>t_{\text {tabel }}\end{array}$ & Ha diterima \\
$107^{\circ} 00^{\prime}$ & 9,58 & 1,73 & \\
$108^{\circ} 00^{\prime}$ & 13,80 & 1,73 & $\begin{array}{l}t_{\text {hitung }} \\
>t_{\text {tabel }}\end{array}$ & Ha diterima \\
\hline
\end{tabular}

Kesimpulan hipotesis didapatkan pada lintasan $105^{\circ} 00^{\prime}, 106^{\circ} 00^{\prime}, 107^{\circ} 00^{\prime}$ dan $108^{\circ} 00^{\prime}$ yaitu semua menyatakan $\mathrm{Ha}$ diterima. Jadi, terdapat perbedaan hasil pengamatan rata-rata tinggi gelombang laut menggunakan metode BratAlgoFilterLoessGrid dengan metode Windwaves-05. Untuk melihat grafik komparasi data dengan grafik regresi komparasi data dapat dilihat pada Gambar 6 dan Gambar 7.

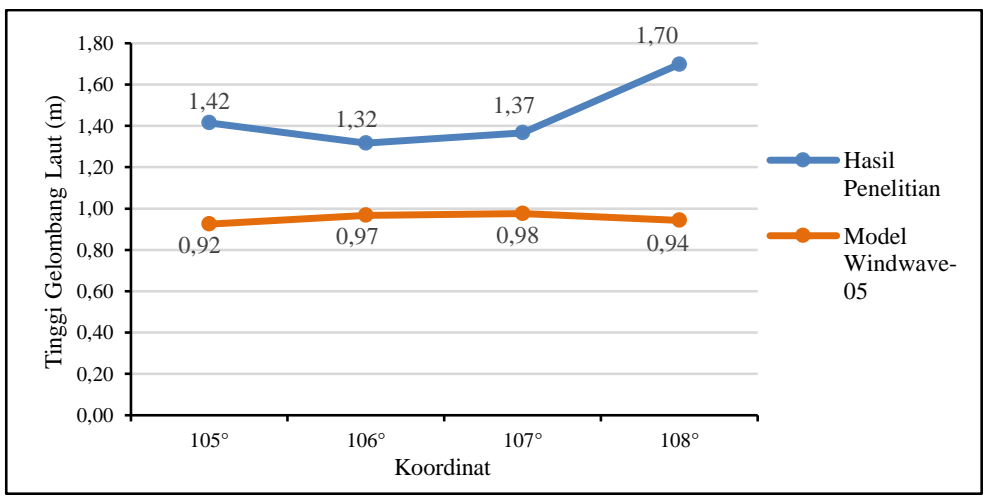

Gambar 6. Grafik Komparasi Data

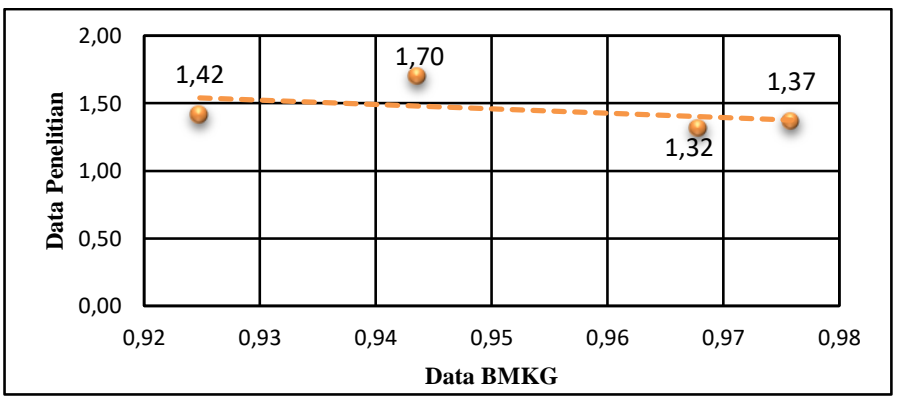

Gambar 7. Grafik Regresi Komparasi Data

Perbandingan model hasil penelitian dengan hasil running model Windwave-05 oleh BMKG dapat dilihat pada Gambar 8 dan Gambar 9. Perbedaan yang dapat dilihat dari kedua peta tersebut yaitu pola persebaran tinggi gelombangnya. Setiap model pasti memiliki kelebihan dan kelemahannya masing-masing dalam melakukan pengolahan data. Hasil penelitian memiliki kelebihan pada pengamatan wilayah laut terbuka karena datanya langsung diamati oleh satelit altimetri dan memiliki kelemahan pada pengamatan wilayah pesisir dikarenakan data waveform yang mendekati daratan memiliki nilai noise yang lebih besar [9]. Sedangkan data hasil running model Windwave05 oleh BMKG memiliki kelebihan pengamatan di pesisir karena adanya data pendukung dari pengamatan langsung pada daerah pesisir dan 
memiliki kelemahan pada wilayah laut terbuka dimana data pendukungnya didapatkan dari pendekatan model lain [10]. Oleh karena itu, sebaiknya dalam melakukan pengamatan di laut terbuka menggunakan data pengamatan satelit altimetri dan untuk pengamatan wilayah sekitar pesisir menggunakan data hasil running model Windwave-05 oleh BMKG.

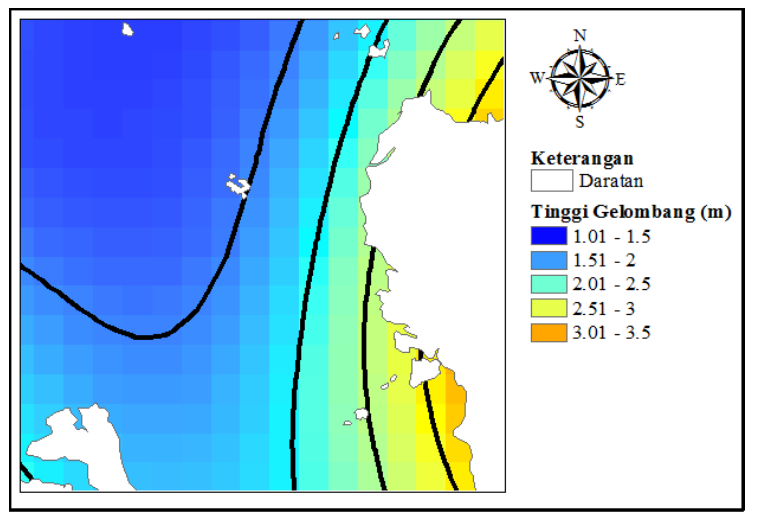

Gambar 8. Hasil Perhitungan Tinggi Gelombang Laut Signifikan Tahun 2007 - 2016

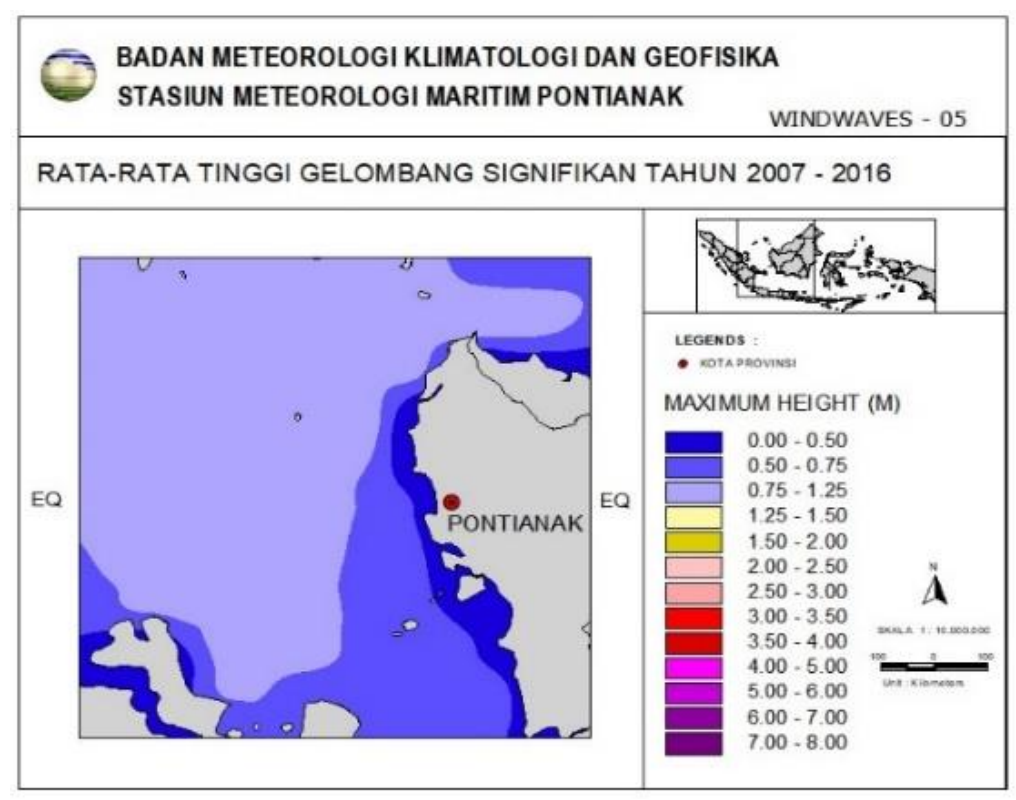

Gambar 9. Peta Rata-Rata Tinggi Gelombang Signifikan Tahun 2007 - 2016

\subsection{Tinggi Gelombang Laut}

Tinggi gelombang di Laut Natuna rata-rata tingginya sebesar $1,41 \mathrm{~m}$, dengan tinggi gelombang minimum sebesar $1,19 \mathrm{~m}$ dan maksimum sebesar $1,92 \mathrm{~m}$. Satelit altimetri memiliki kelemahan pada pengamatan di wilayah pesisir karena sinyal yang dipancarkan satelit altimetri mengalami gangguan pemantulan oleh adanya daratan sehingga waveform yang mendekati daratan memiliki nilai noise lebih besar. Penjelasan inilah yang menyebabkan wilayah setiap segmen dekat pesisir daratan rata-rata memiliki nilai gelombang yang besar. Kabupaten Kayong Utara dan Kabupaten Ketapang merupakan contoh wilayah pesisir yang memiliki nilai noise relatif besar.
Dari Tabel 3 dapat diketahui tinggi gelombang 10 tahun terakhir di segmen A sebesar 1,19 m s.d 1,68 m, segmen B sebesar 1,28 m s.d 1,89 m, dan segmen $C$ sebesar 1,54 m s.d 1,92 m. Kejadian tinggi gelombang terendah yang teramati terdapat pada tahun $2012 \mathrm{di}$ segmen A yaitu sebesar 0,96 m, sedangkan kejadian tinggi gelombang tertinggi yang teramati terdapat pada tahun 2010 di segmen C yaitu sebesar 2,63 m. 
Tabel 4. Hasil Perhitungan Tinggi Gelombang Laut Signifikan

\begin{tabular}{|c|c|c|c|c|}
\hline \multirow{2}{*}{ No } & \multirow{2}{*}{$\begin{array}{c}\text { Waktu } \\
\text { Pengamatan }\end{array}$} & \multicolumn{3}{|c|}{ Segmen (meter) } \\
\hline & & $\mathrm{A}$ & $\mathrm{B}$ & $\mathrm{C}$ \\
\hline 1. & $\begin{array}{c}\text { Tahun } 2007 \\
-2016\end{array}$ & $\begin{array}{c}1,19 \mathrm{~m} \mathrm{~s} . \mathrm{d} \\
1,68 \mathrm{~m}\end{array}$ & $\begin{array}{c}1,28 \mathrm{~m} \mathrm{~s} . \mathrm{d} \\
1,89 \mathrm{~m}\end{array}$ & $\begin{array}{c}1,54 \mathrm{~m} \mathrm{~s} . \mathrm{d} \\
1,92 \mathrm{~m}\end{array}$ \\
\hline 2. & Tahun 2007 & $\begin{array}{c}1,15 \mathrm{~m} \mathrm{~s} . \mathrm{d} \\
1,63 \mathrm{~m}\end{array}$ & $\begin{array}{c}1,18 \mathrm{~m} \mathrm{~s} . \mathrm{d} \\
1,78 \mathrm{~m}\end{array}$ & $\begin{array}{c}1,29 \mathrm{~m} \mathrm{~s} . \mathrm{d} \\
1,82 \mathrm{~m}\end{array}$ \\
\hline 3. & Tahun 2008 & $\begin{array}{c}1,33 \mathrm{~m} \mathrm{~s} . \mathrm{d} \\
1,88 \mathrm{~m}\end{array}$ & $\begin{array}{c}1,39 \mathrm{~m} \text { s.d } \\
2,17 \mathrm{~m}\end{array}$ & $\begin{array}{c}1,39 \mathrm{~m} \text { s.d } \\
2,18 \mathrm{~m}\end{array}$ \\
\hline 4. & Tahun 2009 & $\begin{array}{c}1,29 \mathrm{~m} \mathrm{s.d} \\
1,81 \mathrm{~m}\end{array}$ & $\begin{array}{c}1,43 \mathrm{~m} \mathrm{s.d} \\
2,06 \mathrm{~m}\end{array}$ & $\begin{array}{c}1,68 \mathrm{~m} \mathrm{s.d} \\
2,17 \mathrm{~m}\end{array}$ \\
\hline 5. & Tahun 2010 & $\begin{array}{c}1,09 \mathrm{~m} \mathrm{~s} . \mathrm{d} \\
1,88 \mathrm{~m}\end{array}$ & $\begin{array}{c}1,29 \mathrm{~m} \mathrm{~s} . \mathrm{d} \\
2,48 \mathrm{~m}\end{array}$ & $\begin{array}{c}1,64 \mathrm{~m} \mathrm{~s} . \mathrm{d} \\
2,63 \mathrm{~m}\end{array}$ \\
\hline 6. & Tahun 2011 & $\begin{array}{c}1,19 \mathrm{~m} \mathrm{~s} . \mathrm{d} \\
1,89 \mathrm{~m}\end{array}$ & $\begin{array}{c}1,31 \mathrm{~m} \mathrm{~s} . \mathrm{d} \\
2,20 \mathrm{~m}\end{array}$ & $\begin{array}{c}1,55 \mathrm{~m} \mathrm{~s} . \mathrm{d} \\
2,30 \mathrm{~m}\end{array}$ \\
\hline 7. & Tahun 2012 & $\begin{array}{c}0,96 \mathrm{~m} \mathrm{~s} . \mathrm{d} \\
1,40 \mathrm{~m}\end{array}$ & $\begin{array}{c}1,03 \mathrm{~m} \mathrm{s.d} \\
1,85 \mathrm{~m}\end{array}$ & $\begin{array}{c}1,25 \mathrm{~m} \mathrm{~s} . \mathrm{d} \\
1,99 \mathrm{~m}\end{array}$ \\
\hline 8. & Tahun 2013 & $\begin{array}{c}1,11 \mathrm{~m} \mathrm{~s} . \mathrm{d} \\
1,60 \mathrm{~m}\end{array}$ & $\begin{array}{c}1,10 \mathrm{~m} \mathrm{~s} . \mathrm{d} \\
1,64 \mathrm{~m}\end{array}$ & $\begin{array}{c}1,14 \mathrm{~m} \mathrm{~s} . \mathrm{d} \\
1,69 \mathrm{~m}\end{array}$ \\
\hline 9. & Tahun 2014 & $\begin{array}{c}1,23 \mathrm{~m} \mathrm{s.d} \\
2,08 \mathrm{~m}\end{array}$ & $\begin{array}{c}1,34 \mathrm{~m} \mathrm{~s} . \mathrm{d} \\
1,91 \mathrm{~m}\end{array}$ & $\begin{array}{c}1,51 \mathrm{~m} \mathrm{~s} . \mathrm{d} \\
1,96 \mathrm{~m}\end{array}$ \\
\hline 10. & Tahun 2015 & $\begin{array}{c}1,21 \mathrm{~m} \mathrm{s.d} \\
2,02 \mathrm{~m}\end{array}$ & $\begin{array}{c}1,38 \mathrm{~m} \mathrm{s.d} \\
2,15 \mathrm{~m}\end{array}$ & $\begin{array}{c}1,71 \mathrm{~m} \mathrm{s.d} \\
2,24 \mathrm{~m}\end{array}$ \\
\hline 11. & Tahun 2016 & $\begin{array}{c}1,21 \mathrm{~m} \mathrm{~s} . \mathrm{d} \\
1,87 \mathrm{~m}\end{array}$ & $\begin{array}{c}1,38 \mathrm{~m} \mathrm{~s} . \mathrm{d} \\
2,37 \mathrm{~m}\end{array}$ & $\begin{array}{c}1,64 \mathrm{~m} \mathrm{~s} . \mathrm{d} \\
2,53 \mathrm{~m}\end{array}$ \\
\hline
\end{tabular}

\subsection{Skala Laut Douglas}

Karakteristik tinggi gelombang laut selama 10 tahun terakhir menurut skala laut douglas yaitu klasifikasinya berada pada skala 3, 4 dan 5 . Skala 3 menyatakan keadaan lautnya memiliki tinggi gelombang kecil, skala 4 menyatakan tinggi gelombang sedang, dan skala 5 menyatakan tinggi gelombang kasar.

Umumnya di setiap segmen A, B, dan C yang dilihat pada Tabel 5, nilai skala laut douglas di Perairan Laut Natuna berada di skala 4. Hal tersebut menyatakan bahwa karakteristik gelombang di Perairan Laut Natuna rata-rata memiliki tinggi gelombang sedang dan petanya dapat dilihat pada Gambar 10.

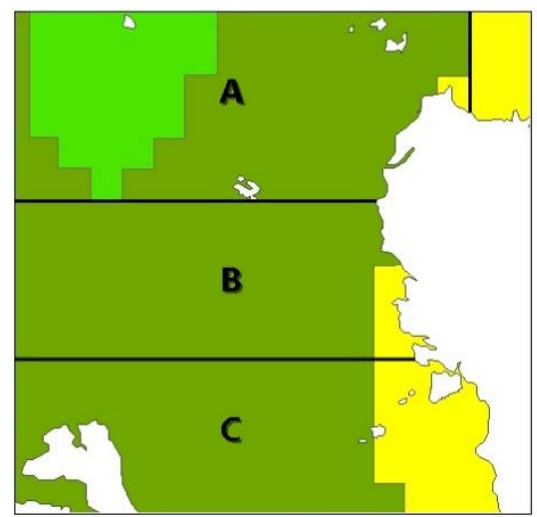

Keterangan

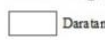

Skala Douglas

Gambar 10. Hasil Pengamatan Karakteristik Tinggi Gelombang Laut Tahun 2007 - 2016
Tabel 5. Hasil Pengamatan Karakteristik Tinggi Gelombang Laut

\begin{tabular}{ccccc}
\hline \multirow{2}{*}{ No } & Waktu & \multicolumn{3}{c}{ Segmen (skala douglas) } \\
\cline { 3 - 5 } & Pengamatan & A & B & C \\
\hline 1. & Tahun 2007 & 3,4 & $3,4,5$ & 4,5 \\
2. & Tahun 2008 & 4,5 & 4,5 & 4,5 \\
3. & Tahun 2009 & 4 & 4,5 & 4,5 \\
4. & Tahun 2010 & $3,4,5$ & 4,5 & 4,5 \\
5. & Tahun 2011 & 3,4 & 4 & 4,5 \\
6. & Tahun 2012 & 3,4 & 3,4 & 4,5 \\
7. & Tahun 2013 & 3,4 & 3,4 & $3,4,5$ \\
8. & Tahun 2014 & 3,4 & 4,5 & 4,5 \\
9. & Tahun 2015 & 3,4 & 4,5 & 4,5 \\
10. & Tahun 2016 & 3,4 & 4,5 & 4,5 \\
\hline
\end{tabular}

\section{Kesimpulan}

Berdasarkan hasil dari penelitian yang telah dilakukan. Ada berapa kesimpulan yang dapat diambil, diantaranya :

1. Tinggi gelombang laut selama 10 tahun terakhir di Perairan Laut Natuna didapatkan nilai rata-rata tinggi gelombang laut sebesar 1,41 m. Tinggi gelombang minimum sebesar $1,19 \mathrm{~m}$ dan maksimumnya 1,92 m, dan

2. Karakteristik tinggi gelombang lautnya didapatkan berada di skala 4, ini menyatakan bahwa karakteristik gelombang laut di Perairan Laut Natuna rata-rata memiliki tinggi gelombang sedang yaitu antara 1,25 m s.d 2,5 m.

\section{Daftar Pustaka}

[1] Kurniawan, 2012, Karakteristik Gelombang Laut dan Daerah Rawan Gelombang Tinggi Di Perairan Indonesia, Universitas Indonesia, Fakultas Ilmu Pengetahuan Alam, Jakarta, (Tesis)

[2] World Meteorolgical Organization (WMO). (2001). Guide the marine meteorological services,Third Edition, WMO no.471. Secretariat of the World Meteorological Organisation, Geneva-Switzerland: Author.

[3] Mulyadi, Jumarang M. I., dan Apriansyah 2015. Studi Variabilitas Tinggi dan Periode Gelombang Laut Signifikan di Selat Karimata. POSITRON, Vol. V, No. 1 (2015), Hal. 19 - 25

[4] Scharroo, R., 2018. RADS User Manual. RADS. United States

[5] Scharroo, R., 2018. RADS Data Manual. RADS. United States

[6] Bonekamp,H. et al., 2017 OSTM/Jason-2 Products Handbook. EUM/OPS-JAS/MAN/ 08/0041. EUMETSAT

[7] BRAT development team, 2017. Software User Manual. 1.5 penyunt. ESA 
[8] Douglas, 2017. Douglas Sea Scale, The Douglas Archives. United Kingdom

[9] Rosmorduc, V. et al., 2016, Radar Altimetry Tutorial, UCL, United Kingdom

[10]Suratno, 2008. Pemanfaatan Data Luaran Model Prakiraan Cuaca Conformal-Cubic Atmospheric Model (CCAM) Sebagai Input Model Gelombang Windwave-05. Jurnal Meteorologi dan Geofisika, Vol 12, No. 1 (2011) Hal. 73-86 